University of Nebraska - Lincoln

DigitalCommons@University of Nebraska - Lincoln

USDA National Wildlife Research Center - Staff Publications
U.S. Department of Agriculture: Animal and Plant Health Inspection Service

2019

\title{
Analysis of Iophenoxic Acid Analogues in Small Indian Mongoose (Herpestes Auropunctatus) Sera for Use as an Oral Rabies Vaccination Biological Marker
}

\author{
Are R. Berentsen \\ USDA APHIS Wildlife Services NWRC, Are.R.Berentsen@aphis.usda.gov \\ Robert T. Sugihara \\ USDA APHIS Wildlife Services NWRC \\ Cynthia G. Payne \\ USDA APHIS Wildlife Services NWRC \\ Israel Leinbach \\ USDA APHIS Wildlife Services NWRC

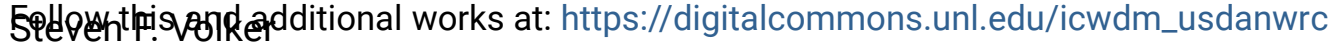 \\ ¿PAaft of the Wildlife Serviges NWRC Conservation Commons, Natural Resources Management and \\ Policy Commons, Other Environmental Sciences Commons, Other Veterinary Medicine Commons,

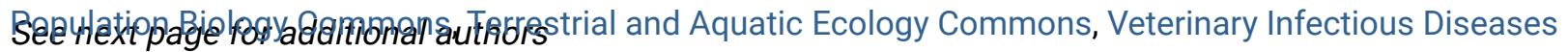 \\ Commons, Veterinary Microbiology and Immunobiology Commons, Veterinary Preventive Medicine, \\ Epidemiology, and Public Health Commons, and the Zoology Commons
}

Berentsen, Are R.; Sugihara, Robert T.; Payne, Cynthia G.; Leinbach, Israel; Volker, Steven F.; Vos, Ad; Ortmann, Steffen; and Gilbert, Amy T., "Analysis of Iophenoxic Acid Analogues in Small Indian Mongoose (Herpestes Auropunctatus) Sera for Use as an Oral Rabies Vaccination Biological Marker" (2019). USDA National Wildlife Research Center - Staff Publications. 2261.

https://digitalcommons.unl.edu/icwdm_usdanwrc/2261

This Article is brought to you for free and open access by the U.S. Department of Agriculture: Animal and Plant Health Inspection Service at DigitalCommons@University of Nebraska - Lincoln. It has been accepted for inclusion in USDA National Wildlife Research Center - Staff Publications by an authorized administrator of DigitalCommons@University of Nebraska - Lincoln. 


\section{Authors}

Are R. Berentsen, Robert T. Sugihara, Cynthia G. Payne, Israel Leinbach, Steven F. Volker, Ad Vos, Steffen Ortmann, and Amy T. Gilbert 


\title{
Video Article \\ Analysis of lophenoxic Acid Analogues in Small Indian Mongoose (Herpestes Auropunctatus) Sera for Use as an Oral Rabies Vaccination Biological Marker
}

\author{
Are R. Berentsen ${ }^{1}$, Robert T. Sugihara ${ }^{1}$, Cynthia G. Payne ${ }^{1}$, Israel Leinbach ${ }^{1}$, Steven F. Volker ${ }^{1}$, Ad Vos $^{2}$, Steffen Ortmann ${ }^{2}$, Amy T. Gilbert $^{1}$ \\ ${ }^{1}$ US Department of Agriculture, Animal and Plant Health Inspection Service, Wildlife Services, National Wildlife Research Center \\ ${ }^{2}$ IDT Biologika GmbH, Am Pharmapark
}

Correspondence to: Are R. Berentsen at Are.R.Berentsen@aphis.usda.gov

URL: https://www.jove.com/video/59373

DOI: doi: $10.3791 / 59373$

Keywords: Immunology and Infection, Issue 147, biological marker, Herpestes auropunctatus, iophenoxic acid, rabies, small Indian mongoose, LC$\mathrm{MS} / \mathrm{MS}$

\section{Date Published: 5/31/2019}

Citation: Berentsen, A.R., Sugihara, R.T., Payne, C.G., Leinbach, I., Volker, S.F., Vos, A., Ortmann, S., Gilbert, A.T. Analysis of lophenoxic Acid Analogues in Small Indian Mongoose (Herpestes Auropunctatus) Sera for Use as an Oral Rabies Vaccination Biological Marker. J. Vis. Exp. (147), e59373, doi:10.3791/59373 (2019).

\section{Abstract}

The small Indian mongoose (Herpestes auropunctatus) is a reservoir of rabies virus (RABV) in Puerto Rico and comprises over $70 \%$ of animal rabies cases reported annually. The control of RABV circulation in wildlife reservoirs is typically accomplished by a strategy of oral rabies vaccination (ORV). Currently no wildlife ORV program exists in Puerto Rico. Research into oral rabies vaccines and various bait types for mongooses has been conducted with promising results. Monitoring the success of ORV relies on estimating bait uptake by target species, which typically involves evaluating a change in RABV neutralizing antibodies (RVNA) post vaccination. This strategy may be difficult to interpret in areas with an active wildlife ORV program or in areas where RABV is enzootic and background levels of RVNA are present in reservoir species. In such situations, a biomarker incorporated with the vaccine or the bait matrix may be useful. We offered 16 captive mongooses placebo ORV baits containing ethyl-iophenoxic acid (et-IPA) in concentrations of $0.4 \%$ and $1 \%$ inside the bait and $0.14 \%$ in the external bait matrix. We also offered 12 captive mongooses ORV baits containing methyl-iophenoxic acid (me-IPA) in concentrations of $0.035 \%, 0.07 \%$ and $0.14 \%$ in the external bait matrix. We collected a serum sample prior to bait offering and then weekly for up to eight weeks post offering. We extracted Iophenoxic acids from sera into acetonitrile and quantified using liquid chromatography/mass spectrometry. We analyzed sera for et-IPA or me-IPA by liquid chromatography-mass spectrometry. We found adequate marking ability for at least eight and four weeks for et- and me-IPA, respectively. Both IPA derivatives could be suitable for field evaluation of ORV bait uptake in mongooses. Due to the longevity of the marker in mongoose sera, care must be taken to not confound results by using the same IPA derivative during consecutive evaluations.

\section{Video Link}

The video component of this article can be found at https://www.jove.com/video/59373/

\section{Introduction}

Rabies virus (RABV) is a negative sense single stranded lyssavirus, and circulates among diverse wildlife reservoir species within the orders Carnivora and Chiroptera. Multiple species of mongoose are reservoirs of RABV, and the small Indian mongoose (Herpestes auropunctatus) is the only reservoir in Puerto Rico and other Caribbean islands in the Western Hemisphere ${ }^{1,2,3}$. The control of RABV circulation in wildlife reservoirs is typically accomplished through a strategy of oral rabies vaccination (ORV). In the United States (US), this management activity is coordinated by the USDA/APHIS/Wildlife Services National Rabies Management Program (NRMP) ${ }^{4}$. Currently no wildlife ORV program exists in Puerto Rico. Research into rabies vaccines and various bait types for mongooses has been conducted with promising results suggesting an ORV program for mongooses is possible ${ }^{5,6,7,8}$.

Monitoring the impact of ORV relies on estimating bait uptake by target species, which typically involves evaluating a change in RV antibody seroprevalence. However, this strategy may be challenging in areas with an active wildlife ORV programs or in areas where RV is enzootic and background levels of RABV neutralizing antibodies (RVNA) are present in reservoir species. In such situations, a biomarker included in the bait or the external bait matrix may be useful.

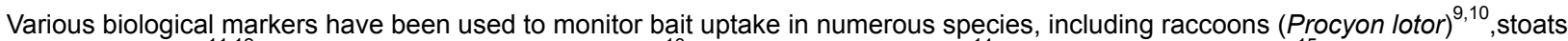

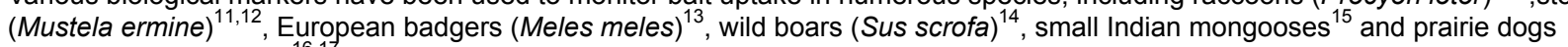
(Cynomysludovicianus) $^{16,17}$, among others. In the US, operational ORV baits often include a $1 \%$ tetracycline biomarker in the bait matrix to monitor bait uptake ${ }^{18,19}$. However, drawbacks to the use of tetracycline include a growing concern over the distribution of antibiotics into the environment and that detection of tetracycline is typically invasive, requiring tooth extraction or destruction of the animal to obtain bone samples ${ }^{20}$. Rhodamine $B$ has been evaluated as a marker in a variety of tissues and can be detected using ultraviolet (UV) light and fluorescence in hair and whiskers ${ }^{10,21}$. 
lophenoxic acid (IPA) is a white, crystalline powder that has been used to evaluate bait consumption in coyotes (Canis latrans) ${ }^{22}$, arctic fox (Vulpes lagopus) ${ }^{23}$, red fox (Vulpes vulpes) ${ }^{24}$, raccoons ${ }^{9,25}$, wild boar ${ }^{14}$, red deer (Cervus elaphus scoticus) ${ }^{26}$, European badgers ${ }^{12}$ and ferrets $(M \text {. furo })^{27}$, among several other mammalian species. Retention times of IPA varies by species from less than two weeks in some marsupials ${ }^{28,29}$, to at least 26 weeks in ungulates ${ }^{26}$ and over 52 weeks in domestic dogs (Canis lupus familiaris) ${ }^{30}$. Retention times may also be dose-dependent ${ }^{31}$. lophenoxic acid binds strongly to serum albumin and was historically detected by measuring blood iodine levels ${ }^{32}$. This indirect approach was supplanted by high-performance liquid chromatography (HPLC) methods to directly measure iophenoxic acid concentrations with UV detection ${ }^{33}$, and eventually with liquid chromatography and mass spectrometry (LCMS) ${ }^{34,35}$. For this study, a highly sensitive and selective liquid chromatography with tandem mass spectrometry (LC-MS/MS) method was developed that utilizes multiple reaction monitoring (MRM) to quantify two analogues of iophenoxic acid. Our objective was to use this LC-MS/MS method to evaluate the marking ability of 2-(3-hydroxy-2,4,6-triiodobenzyl)propanoic acid (methyl-IPA or me-IPA) and 2-(3-hydroxy-2,4,6-triiodobenzyl)butanoic acid (ethyl-IPA or etIPA) and when delivered in an ORV bait to captive mongooses.

Mongooses were live captured in cage traps baited with commercially available smoked sausages and fish oil. Mongooses were housed in individual $60 \mathrm{~cm} \times 60 \mathrm{~cm} \times 40 \mathrm{~cm}$ stainless steel cages and fed a daily ration of $\sim 50 \mathrm{~g}$ commercial dry cat food, supplemented twice per week with a commercially available chicken thigh. Water was available ad libitum. We delivered two derivatives of IPA, ethyl-IPA and methyl-IPA, to captive mongooses in placebo ORV baits. All baits were composed of a $28 \mathrm{~mm} \times 20 \mathrm{~mm} \times 9 \mathrm{~mm}$ foil blister pack with an external coating (hereafter "bait matrix") containing powdered chicken egg and gelatin (Table of Materials). Baits contained $0.7 \mathrm{~mL}$ of water or IPA derivative and weighed approximately $3 \mathrm{~g}$, of which $\sim 2 \mathrm{~g}$ was the external bait matrix.

We offered 16 captive mongooses et-IPA in three concentrations: $0.14 \%$ (2.8 mg et-IPA in $\sim 2 \mathrm{~g}$ bait matrix; $3 \mathrm{males} \mathrm{[m],} 3 \mathrm{females}$ [f]), $0.4 \%$ (2.8 $\mathrm{mg}$ et-IPA in $0.7 \mathrm{~mL}$ blister pack volume; $3 \mathrm{~m}, 3 \mathrm{f})$, and $1.0 \%$ (7.0 mg ethyl-IPA in $0.7 \mathrm{~mL}$ blister pack volume; $2 \mathrm{~m}, 2 \mathrm{f})$. The overall dose of $2.8 \mathrm{mg}$ corresponds to a dose rate of $5 \mathrm{mg} / \mathrm{kg}^{27,36}$ and is based on an average mongoose weight of $560 \mathrm{~g}$ in Puerto Rico. We selected $1 \%$ as the highest concentration as research suggests taste aversion to some biomarkers may occur at concentrations $>1 \%$ in some species ${ }^{37}$. We only offered the $1 \%$ dose in the blister pack as flocculation prevented the solute from dissolving in the solvent sufficiently to be evenly incorporated into the bait matrix. One control group $(2 \mathrm{~m}, 1 \mathrm{f})$ received baits filled with sterile water and no IPA. We offered baits to mongooses in the morning ( $~ 8$ a.m.) during or prior to feeding of their daily maintenance ration. Bait remains were removed after approximately 24 hours. We collected blood samples prior to treatment, one day post-treatment and then weekly up to 8 weeks post-treatment. We anesthetized mongooses by inhalation of isoflurane gas and collected up to $1.0 \mathrm{~mL}$ of whole blood by venipuncture of the cranial vena cava as described for ferrets ${ }^{38}$. We centrifuged whole blood samples, transferred sera to cryovials and stored them at $-80^{\circ} \mathrm{C}$ until analysis. Not all animals were sampled during all time periods to minimize the impacts of repeated blood draws on the health of the animals. Control animals were sampled on day 0 , then weekly for up to 8 weeks post-treatment.

We delivered me-IPA in three concentrations: $0.035 \%(0.7 \mathrm{mg}), 0.07 \%(1.4 \mathrm{mg})$ and $0.14 \%(2.8 \mathrm{mg})$, all incorporated into the bait matrix, with 2 males and 2 females per treatment group. Two males and two females received baits filled with sterile water and no IPA. Bait offering times and mongoose anesthesia are described above. We collected blood samples prior to treatment on day 1 , and then weekly up to 4 weeks posttreatment.

We tested serum concentration data for normality and estimated means for serum IPA concentrations of different treatment groups. We used a linear mixed model to compare mean serum et-IPA concentrations pooled across individuals. Bait type (matrix/blister pack) was a fixed effect in addition to experimental day, whereas animal ID was a random effect. All procedures were run using common statistical software (Table of Materials) and significance was evaluated at $\alpha=0.05$.

\section{Protocol}

All procedures were approved by the USDA National Wildlife Research Center's institutional Animal Care and Use Committee under approved research protocol QA-2597.

NOTE: The following protocol describes the analysis procedure to detect methyl-iophenoxic acid in mongoose serum. This method is the final version of an iterative process that began with analysis of ethyl-iophenoxic acid in mongoose serum. During the initial evaluation of ethyliophenoxic acid minor modifications were made to the methods, resulting in the final protocol presented below. Representative results include those obtained during both iterations.

\section{Preparation of solutions and standards}

1. Purchase me-IPA and et-IPA.

2. For mobile phase $A$, prepare $1 \mathrm{~L}$ of $0.1 \%(\mathrm{v} / \mathrm{v})$ formic acid in water by combining $1 \mathrm{~mL}$ of formic acid with $1 \mathrm{~L}$ of ultrapure water $(\geq 18 \mathrm{M} \Omega)$. For mobile phase $B$, prepare $1 \mathrm{~L}$ of $0.1 \%(\mathrm{v} / \mathrm{v})$ formic acid in acetonitrile $(\mathrm{ACN})$ by combining $1 \mathrm{~mL}$ of formic acid with $1 \mathrm{~L}$ of $A C N$.

3. For diluent, prepare $200 \mathrm{~mL}$ of $0.5 \%$ (v/v) trifluoroacetic acid (TFA) in ACN by combining $1 \mathrm{~mL}$ of TFA with $200 \mathrm{~mL}$ of $A C N$.

4. Prepare concentrated IPA stock solutions of me-IPA and et-IPA in ACN at concentrations of approximately $1,000 \mu \mathrm{g} / \mathrm{mL}$.

1. Weigh approximately $10 \mathrm{mg}$ of me-IPA on a microbalance and record the mass to $\pm 0.0001 \mathrm{mg}$. Quantitatively transfer the me-IPA to a $10 \mathrm{~mL}$ Class A volumetric flask using $45 \mathrm{~mL} \mathrm{ACN}$. Sonicate $1 \mathrm{~min}$ to dissolve all solids, and then bring to volume with ACN.

2. Transfer $\sim 8 \mathrm{~mL}$ of each stock to amber $8 \mathrm{~mL}$ glass vials with poly-tetrafluoroethylene (PTFE)-lined caps. Store at room temperature (RT). Transfer the remaining stock to hazardous waste.

5. For the 25x-7 me-IPA stock (Table 1), prepare a stock of me-IPA in ACN at approximately $200 \mu \mathrm{g} / \mathrm{mL}$. Example: Transfer $1 \mathrm{~mL}$ of the me-IPA concentrated stock from step 1.4.2 to a $5 \mathrm{~mL}$ Class A volumetric flask using a 1,000 $\mu \mathrm{L}$ glass syringe. Dilute to volume with ACN. Transfer the stock to an amber $8 \mathrm{~mL}$ glass vial with PTFE-lined cap. Store at RT.

6. Prepare the six additional $25 x$ me-IPA Stocks described in Table 1. For each stock, combine the volumes indicated using a repeat pipettor in an amber $8 \mathrm{~mL}$ amber glass vial with PTFE-lined cap. Store each stock at RT. 
7. For the $25 x$ surrogate stock, prepare a surrogate stock of me-IPA in ACN at approximately $10 \mu \mathrm{g} / \mathrm{mL}$ from the concentrated stock prepared in step 1.4.2. Transfer $0.100 \mathrm{~mL}$ of the concentrated me-IPA stock to a $10 \mathrm{~mL}$ Class A volumetric flask using a $100 \mu \mathrm{L}$ glass syringe, and then dilute to volume with ACN.

1. Transfer $\sim 8 \mathrm{~mL}$ to an amber $8-\mathrm{mL}$ glass vial with PTFE-lined cap. Store at RT. Transfer the remaining stock to hazardous waste.

8. Prepare $4 x$ stocks containing both analytes in $2 \mathrm{~mL}$ screw-top glass autosampler vials as described in Table 2.

1. For example, to prepare stock $4 x-7$, to a $2 \mathrm{~mL}$ vial, add $0.20 \mathrm{~mL}$ of the $25 \mathrm{x}-7$ me-IPA stock from step 1.5 using a repeat pipettor with $0.5 \mathrm{~mL}$ capacity tip. Add $0.20 \mathrm{~mL}$ of the $25 x$ surrogate et-IPA stock from step 1.7 using a repeat pipettor with $0.5 \mathrm{~mL}$ capacity tip.

2. Add $0.85 \mathrm{~mL}$ of $A C N$ using a repeat pipettor with $1 \mathrm{~mL}$ capacity tip. Cap the vial securely and invert $5 x$ to mix.

9. Prepare the standard curve in $2 \mathrm{~mL}$ screw-top autosampler vials as described in Table 3.

1. For example, to prepare standard 7 (Std 7), to a $2-\mathrm{mL}$ vial, add $0.20 \mathrm{~mL}$ of the $4 x-7$ Stock from step 1.8 .2 using a repeat pipettor with $0.5 \mathrm{~mL}$ capacity tip. Add $0.60 \mathrm{~mL}$ of ultrapure DI water using a repeat pipettor with $1 \mathrm{~mL}$ capacity tip. Cap the vial securely and invert $5 \mathrm{x}$ to mix.

\section{Sample preparation}

CAUTION: Personnel performing this procedure must have received the full series of rabies pre-exposure prophylaxis and have a documented rabies antibody titer above $0.5 \mathrm{IU}$ from a Federal Occupational Health designated medical facility. Personnel must wear lab coats and eye protection at all times while performing the extraction. CAUTION: Perform steps 2.3-2.6 in a class II biosafety cabinet.

1. For each sample, prepare a $1.5 \mathrm{~mL}$ microcentrifuge tube containing $200-300 \mathrm{mg}$ of $\mathrm{NaCl}$.Arrange the tubes in an 80 -position plastic rack. Set aside for use in step 2.6 .

NOTE: A micro scoop (or other small measuring device) is recommended for large numbers of samples.

2. For each sample, label two $1.5 \mathrm{~mL}$ microcentrifuge tubes: one as "A" and the other as "B". Arrange the tubes in an 80 -position plastic rack.

3. Place the following materials and equipment needed for serum extraction in a class II biosafety cabinet: microcentrifuge tubes (in racks) prepared in steps 2.1 and 2.2, a vortex mixer, repeat pipettor with $0.5 \mathrm{~mL}$ and $5 \mathrm{~mL}$ capacity tips, $100-1,000 \mu \mathrm{L}$ air displacement pipette with $1,000 \mu \mathrm{L}$ tips, containers with approximately $100 \mathrm{~mL}$ each of diluent and ultrapure DI water, and a biohazard waste container.

4. Remove serum samples from frozen storage and warm to RT in the biosafety cabinet. Vortex mix each serum sample prior to sampling.

5. Using a repeat pipettor with $0.5 \mathrm{~mL}$ capacity tip, dispense $0.050 \mathrm{~mL}$ of mongoose serum into tube "A" and add $0.050 \mathrm{~mL}$ of $25 \mathrm{x}$ surrogate stock. Then add $0.950 \mathrm{~mL}$ of diluent to tube "A" using a repeat pipettor with $5 \mathrm{~mL}$ capacity tip. Cap securely and vortex mix for $10-15 \mathrm{~s}$.

6. Dispense the pre-weighed $\mathrm{NaCl}$ from step 2.1 into tube "A" and vortex mix $3 \times$ for $8-12 \mathrm{~s}$. Wipe down the outside surfaces of the vial rack containing tube "A" using $70 \%(\mathrm{v} / \mathrm{v})$ isopropanol. NOTE: The rack of samples may now be removed from the class II biosafety cabinet.

7. Centrifuge tube "A" at $12,000 \times g$ for 1 min to separate the aqueous and $A C N$ phases. Pipette $0.80 \mathrm{~mL}$ of the upper ACN phase to tube "B" using a 100-1,000 $\mu \mathrm{L}$ air displacement pipette. Transfer the remaining solution in tube " $\mathrm{A}$ " to hazardous waste and discard the empty tube in a biohazardous waste container.

8. Remove ACN and TFA from tube "B" with a gentle flow of $\mathrm{N}_{2}$ gas in a $45^{\circ} \mathrm{C}$ water bath.

9. Add $0.250 \mathrm{~mL}$ of $\mathrm{ACN}$ to tube "B" using a repeat pipettor, vortex mix for $4-5 \mathrm{~s}$, and then centrifuge briefly $(2-4 \mathrm{~s})$ at $12,000 \times \mathrm{g}$ to collect the liquid in the bottom of the tube.

10. Add $0.750 \mathrm{~mL}$ of ultrapure $\mathrm{DI}$ water to tube "B" using a repeat pipettor with $5 \mathrm{~mL}$ capacity tip, vortex mix for $4-5 \mathrm{~s}$, and then centrifuge for 1 $\min$ at $12,000 \times g$ to clarify the sample.

11. Transfer $0.75 \mathrm{~mL}$ of the supernatant to an autosampler vial using a $1,000 \mu \mathrm{L}$ air displacement pipette. Discard pipette tips in biohazard waste container.

12. Cap autosampler vials securely and analyze by LC-MS/MS (section 4). Transfer the remaining solution in tube "B" to hazardous waste and discard the empty tube to a biohazardous waste container. Dispose of all biohazardous waste by autoclaving or incineration.

\section{Quality control samples}

\section{CAUTION: Follow the cautionary statements described in section 2.}

NOTE:The following procedure describes the minimum number of quality control (QC) samples required for an analysis. Replicates at each level are recommended if sufficient control mongoose serum is available.

1. Prepare four $1.5 \mathrm{~mL}$ microcentrifuge tubes containing $200-300 \mathrm{mg}$ of $\mathrm{NaCl}$. Arrange the tubes in an 80 -position plastic rack.

2. For each QC sample, label two $1.5 \mathrm{~mL}$ microcentrifuge tubes: one as "A" and the other as "B". Arrange the tubes in an 80 -position plastic rack.

3. Repeat step 2.3

4. Remove control mongoose serum from frozen storage and warm to RT in the biosafety cabinet. Vortex mix the control serum prior to sampling

5. Dispense $0.050 \mathrm{~mL}$ of control mongoose serum into the four $1.5-\mathrm{mL}$ "A" tubes using a repeat pipettor with $0.5 \mathrm{~mL}$ capacity tip.

6. Fortify each of the four QC samples as specified in Table 4 using a repeat pipettor with $0.5 \mathrm{~mL}$ capacity tip. Cap each QC sample securely and vortex mix for $10-15 \mathrm{~s}$.

7. Perform the extraction procedure as described in steps 2.6-2.12. 


\section{LC-MS/MS analysis}

1. Configure the LC-MS/MS with all parameters described in Table 5. Power on the LC-MS/MS and allow the column to reach $70{ }^{\circ} \mathrm{C}$ before setting the flow rate to $0.800 \mathrm{~mL} / \mathrm{min}$.

2. Set up a sequence in the data acquisition software (Table of Materials) to inject the standard curve before and after each batch consisting of quality control samples and unknown samples.

3. Inject all standards and samples and acquire MRM ion chromatograms using parameters listed in Table $\mathbf{5}$

4. After sequence completion, turn off the LC-MS/MS and dispose of all autosampler vials as hazardous waste.

\section{Quantification}

1. Use the data analysis software to generate a calibration curve of relative responses versus relative concentrations for me-IPA using et-IPA as the internal standard. Calculate the relative responses from the quantifier MRM transition for me-IPA (556.6 $\rightarrow$ 428.7) divided by the MRM transition for et-IPA $(570.7 \rightarrow 442.7)$. Construct a 7 -level calibration curve using a second order quadratic function that is weighted $1 / x$ and ignores the origin.

2. Calculate the serum concentration $\left(\mathrm{C}_{\text {serum }}\right)$ of me-IPA using the following equation:

$C_{\text {serum }}=\frac{\left(c_{\text {instrument }}\right)(1.25)\left(V_{\text {final }}\right)}{V_{\text {serum }}}$

where $c_{\text {instrument }}$ is the concentration determined by the instrument from the calibration curve in units of $\mu \mathrm{g} / \mathrm{mL}, 1.25$ is the dilution factor $\left(\frac{1 \mathrm{~mL}}{0.8 \mathrm{~mL}}=1.25\right), \mathrm{V}_{\text {final }}$ is the final sample volume $(1.0 \mathrm{~mL})$, and $\mathrm{V}_{\text {serum }}$ is the serum volume in $\mathrm{mL}(0.050 \mathrm{~mL}$ nominal $)$.

\section{Representative Results}

Representative ion chromatograms from a me-IPA analysis are presented in Figure 1. The control mongoose serum (Figure 1A) illustrates the retention time of et-IPA (surrogate analyte) and the absence of me-IPA at the indicated retention time. The quality control sample (Figure 1B) illustrates the baseline separation of me-IPA from et-IPA as well as the quantifier and qualifier transitions for me-IPA. Figure 1C shows a representative sample from the study with an observed serum concentration of $33.5 \mu \mathrm{g} / \mathrm{mL}$ me-IPA.

A representative calibration curve from a me-IPA analysis is presented in Figure 2. The 7-level, 14-point standard curve ranges from 0.00202 to $8.27 \mu \mathrm{g} / \mathrm{mL}$ me-IPA with a correlation coefficient $\left(r^{2}\right)$ of 0.9998 . Correlation coefficients ranged from 0.9998 to 0.99997 for the five me-IPA analyses. The surrogate analyte et-IPA concentration was $0.502 \mu \mathrm{g} / \mathrm{mL}$ in all standards.

Table 6 presents the accuracy and precision results for control mongoose serum fortified with 0,1.3, 31, and $82 \mu \mathrm{g} / \mathrm{mL} \mathrm{me}-\mathrm{IPA}$ ( $\mathrm{n}=10$ at each level). The results were collected from five separate analyses. Percent recoveries ranged from $96.9 \%$ to $109 \%$. The percent relative standard deviation (\% RSD) at the three fortification levels was $3.4 \%, 1.7 \%$, and $2.3 \%$, respectively.

The signal-to-noise ratio $(\mathrm{S} / \mathrm{N})$ observed in quality control samples $(\mathrm{n}=10$ negative controls; $n=10$ at $1.3 \mu \mathrm{g} / \mathrm{mL}$ me-IPA) was used to determine the detection limit (DL; $3 \times \mathrm{S} / \mathrm{N})$ and quantitation limit (QL; $10 \times \mathrm{S} / \mathrm{N})$. The $\mathrm{DL}$ and $\mathrm{QL}$ for me-IPA in mongoose serum were $0.012 \mu \mathrm{g} / \mathrm{mL}$ and $0.042 \mu \mathrm{g} / \mathrm{mL}$, respectively.

The peak area responses of the qualifier MRM transition divided by the quantifier MRM transition $\left(\frac{556.6 \rightarrow 126.9}{556.6 \rightarrow 428.7}\right)$ was calculated for all standards and samples. This ratio for each sample was then divided by the average ratio observed in the calibration standards to determine the qualifier percent match. The qualifier ratio for the sample shown in Figure $1 \mathrm{C}$ was 0.439 , with a $96.3 \%$ match.

The recovery of et-IPA surrogate analyte was calculated for all QC samples and unknown samples by dividing the et-IPA peak area response by the average et-IPA peak area response observed in the calibration standards. Average surrogate analyte recoveries were $91.0 \%$ (negative controls), $91.4 \%(1.3 \mu \mathrm{g} / \mathrm{mL}), 92.8 \%(31 \mu \mathrm{g} / \mathrm{mL})$, and $95.4 \%(82 \mu \mathrm{g} / \mathrm{mL})$.

No interference peaks for either the quantifier or qualifier transitions of me-IPA were observed in control mongoose serum (Figure 1A).

The extraction procedure and instrumental conditions used to determine et-IPA in mongoose serum (Figure 3 and Table 7) was identical to the me-IPA method, but with the following changes. Propyl-iophenoxic acid (pr-IPA) was used as the surrogate analyte and an older, less sensitive LC-MS/MS was used. The source drying gas temperature was $350{ }^{\circ} \mathrm{C}$ with a flow of $12 \mathrm{~L} / \mathrm{min}$ and a nebulizer pressure of 35 psi. The capillary voltage was $-2,500 \mathrm{~V}$. The source had no sheath gas or means to adjust nozzle voltage. The quantifier MRM transition for et-IPA was $570.7 \rightarrow$ $442.8(584.7 \rightarrow 456.8$ for pr-IPA). The fragmentor was $80 \mathrm{~V}$ and the collision energy was $10 \mathrm{~V}$ for both analytes. The qualifier MRM for et-IPA was $570.7 \rightarrow 126.8$ with a collision energy of $40 \mathrm{~V}$.

The testing of all mongoose serum samples for et-IPA was performed over eight analyses. The 7-level calibration curve ranged from 0.00207 to $8.48 \mu \mathrm{g} / \mathrm{mL}$ with correlation coefficients $\left(r^{2}\right)$ ranging from 0.9990 to 0.9999 . The surrogate analyte pr-IPA concentration was $0.512 \mu \mathrm{g} / \mathrm{mL}$. Table 7 presents the accuracy and precision results for control mongoose serum fortified with $0,1.3,13,32,85$, and $170 \mu \mathrm{g} / \mathrm{mL} \mathrm{me}-\mathrm{IPA}$. The results were collected from eight separate analyses. Percent recoveries ranged from $89.5 \%$ to $115 \%$. The $\%$ RSD at the five fortification levels was $4.3 \%, 1.5 \%, 2.3 \%, 5.6 \%$, and $1.1 \%$, respectively. The S/N observed in quality control samples $(\mathrm{n}=21$ negative controls; $\mathrm{n}=21 \mathrm{at} 1.3 \mu \mathrm{g} / \mathrm{mL} \mathrm{me}-$ IPA) was used to determine the DL and QL. The DL and QL for me-IPA in mongoose serum were $0.12 \mu \mathrm{g} / \mathrm{mL}$ and $0.42 \mu \mathrm{g} / \mathrm{mL}$, respectively. The average surrogate analyte recovery from quality control samples was $86.8 \%(n=75)$. No interference peaks for either the quantifier or qualifier transitions of et-IPA were observed in control mongoose serum. 
All mongooses offered et-IPA baits consumed $\geq 25 \%$ of the bait within the 24 hour time constraint and had quantifiable levels of et-IPA in their sera (Table 8). From the mixed model analysis, overall mean serum IPA concentrations were marginally higher from baits with $2.8 \mathrm{mg}$ of biomarker in the bait matrix $(17.5 \mu \mathrm{g} / \mathrm{mL}, 95 \% \mathrm{Cl} 11.7-23.3 \mu \mathrm{g} / \mathrm{mL})$ in comparison to the blister pack $(9.8 \mu \mathrm{g} / \mathrm{mL}, 95 \% \mathrm{Cl} 4.0-15.6 \mu \mathrm{g} / \mathrm{mL})(\mathrm{F}$ $=3.6, P=0.07)$. Concentrations for both bait types decayed with experimental day $(\beta=-0.15 \pm 0.04, F=14.4, P=0.0005)$. Individual level variability in serum IPA concentrations was observed (animal ID covariance parameter estimate $=46.6 \pm 20.7$ ). All mongooses consumed $100 \%$ of control baits with only the empty foil blister pack remaining. Mean concentration of et-IPA residue in serum was variable by time period and did not appear to decrease consistently over time (Figure 3).

All mongooses offered me-IPA baits consumed $\geq 25 \%$ of the bait within the 24 hour time limit and had quantifiable levels of me-IPA in their sera (Table 9). Mean serologic concentration of et- and me-IPA in mongoose sera appeared dependent upon the concentration of IPA in the bait. Higher concentrations of IPA in the bait resulted in higher serum residues even in cases where the overall dose (2.8 mg in the case of et-IPA) remained the same. Interestingly, me-IPA appeared to produce a more even degradation pattern over time with an initial spike at day 1 , followed by a steady decline until day 14 where concentrations appeared to plateau (Figure 4). 

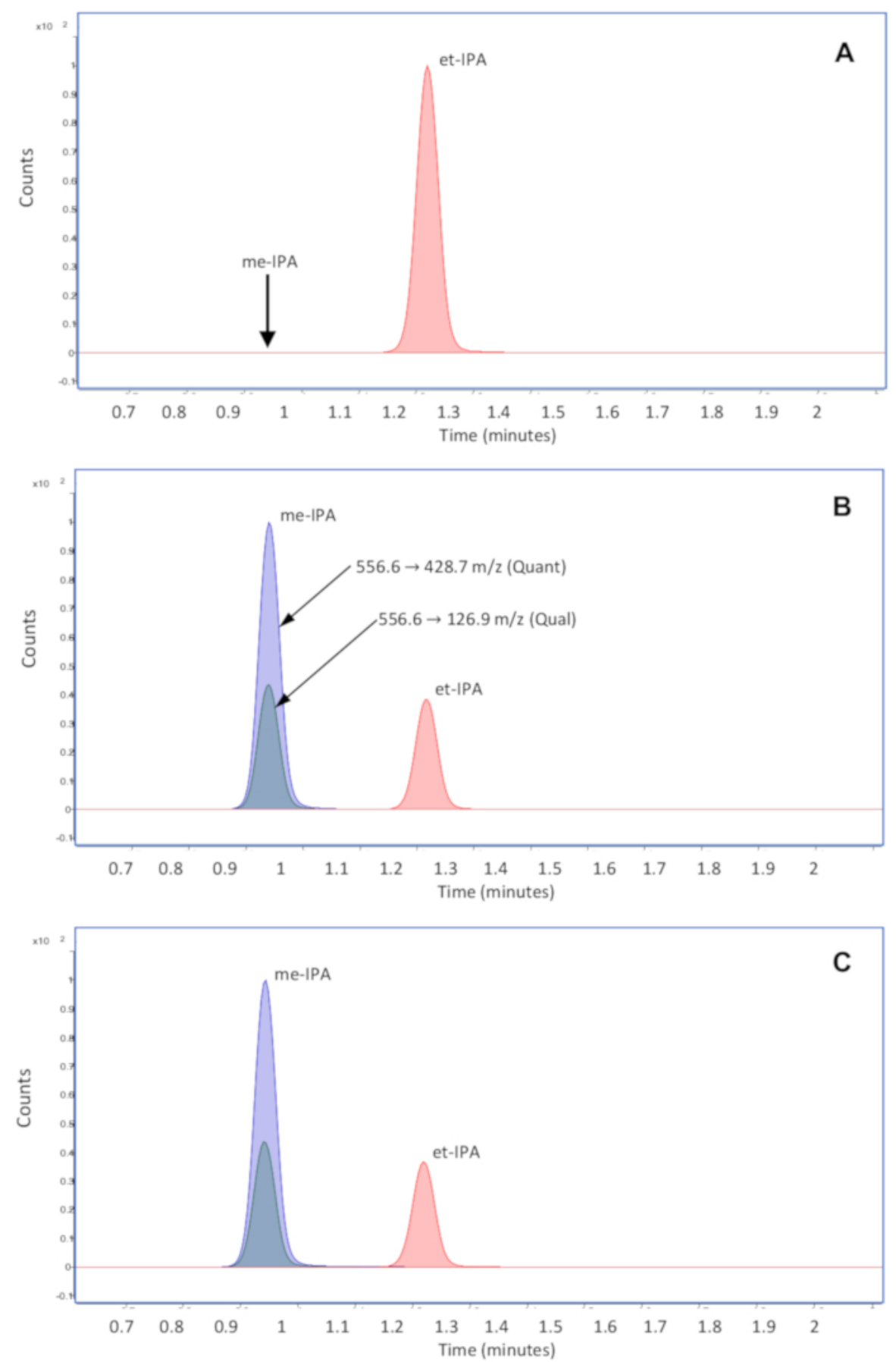

Figure 1: Representative ion chromatograms. (A) Representative MRM ion chromatogram of control mongoose serum fortified with surrogate analyte ethyl-iophenoxic acid (et-IPA). The arrow indicates the retention time for methyl-iophenoxic acid (me-IPA). (B) Representative MRM ion chromatogram of control mongoose serum fortified with $31 \mu \mathrm{g} / \mathrm{mL}$ me-IPA. The relative intensities of the quantifier (Quant) and qualifier (Qual) transitions for me-IPA are shown. (C) Representative MRM ion chromatogram of a mongoose serum sample with an observed me-IPA concentration of $33.5 \mu \mathrm{g} / \mathrm{mL}$. Please click here to view a larger version of this figure. 


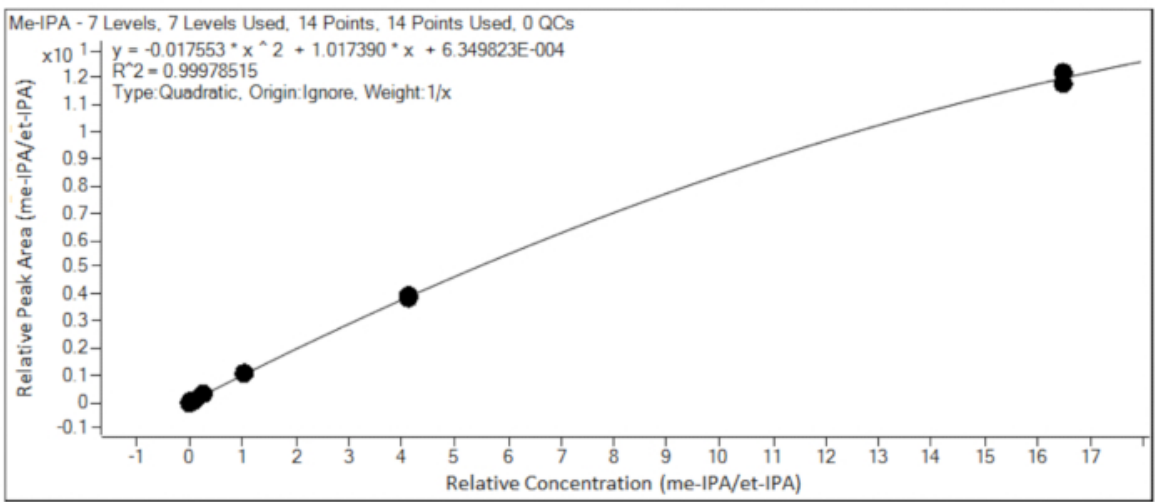

Figure 2: Representative calibration curve. An original calibration curve generated by the data analysis software for methyl-iophenoxic acid (me-IPA). Please click here to view a larger version of this figure.

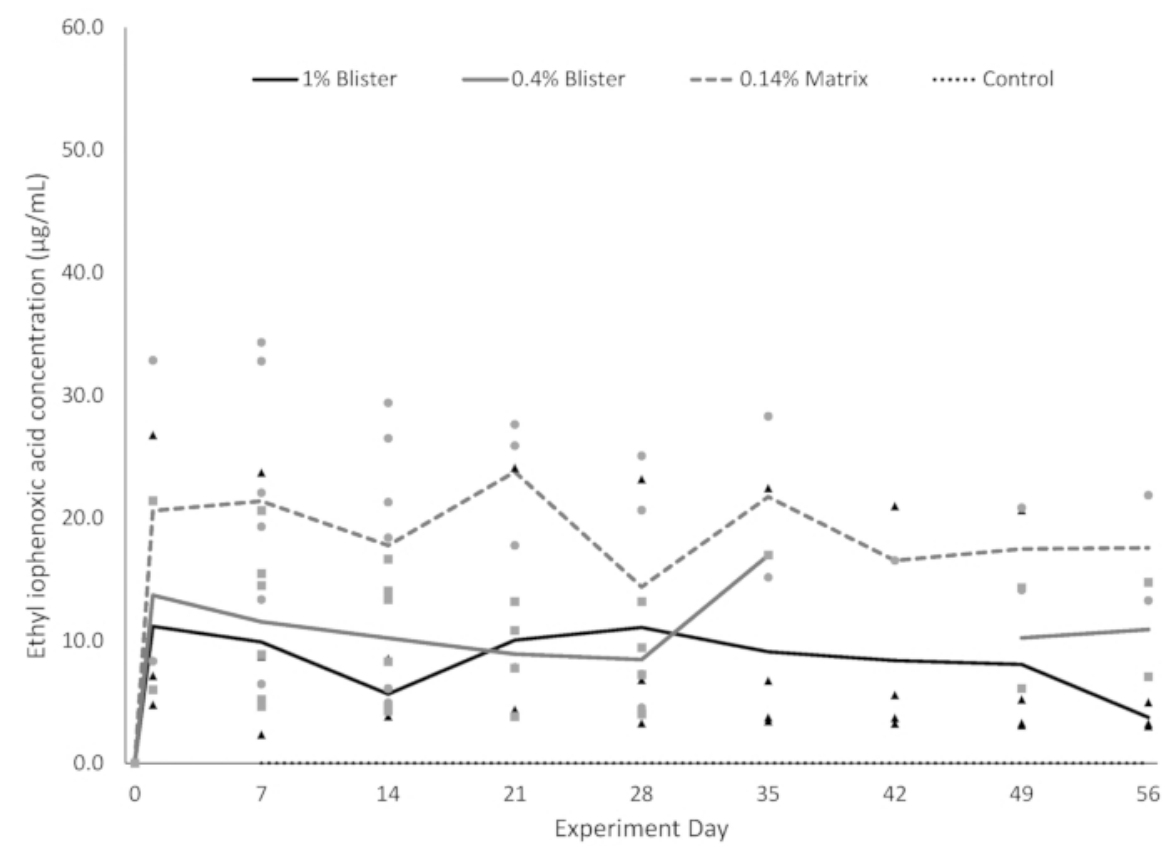

Figure 3: Mean serum ethyl IPA (et-IPA) concentration by bait type and concentration over time. Please click here to view a larger version of this figure. 


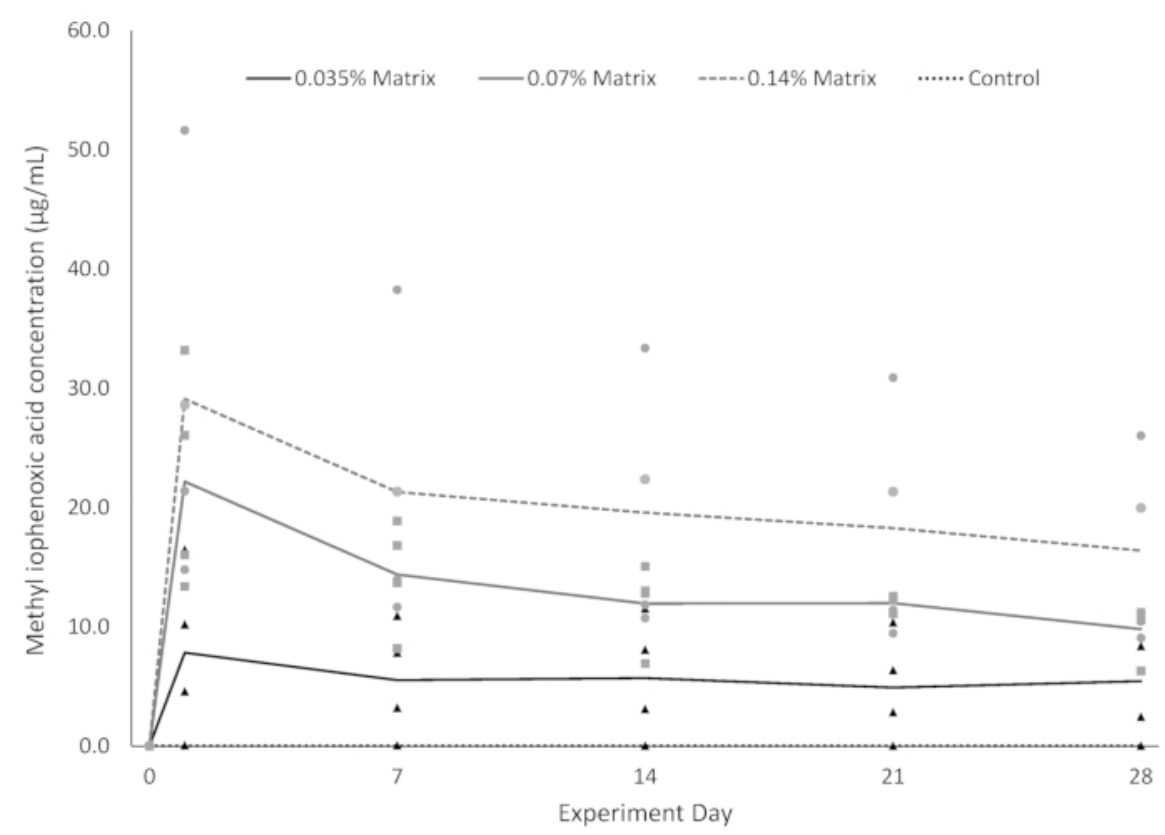

Figure 4: Mean serum methyl IPA (me-IPA) concentration by bait concentration over time. All me-IPA concentrations were incorporated into the external bait matrix. Please click here to view a larger version of this figure.

\begin{tabular}{|l|l|l|}
\hline ID & & me-IPA Concentration $(\mu \mathrm{g} / \mathrm{mL})$ \\
\hline $25 x-7$ & Refer to step 1.6 & 200 \\
\hline $25 x-6$ & $\begin{array}{l}\text { Combine } 1.000 \mathrm{~mL} 25 x-7 \text { Stock with } 3.000 \mathrm{~mL} \\
\text { ACN }\end{array}$ & 50 \\
\hline $25 x-5$ & $\begin{array}{l}\text { Combine } 1.000 \mathrm{~mL} 25 x-6 \text { Stock with } 3.000 \mathrm{~mL} \\
\text { ACN }\end{array}$ & 13 \\
\hline $25 x-4$ & $\begin{array}{l}\text { Combine } 1.000 \mathrm{~mL} 25 x-5 \text { Stock with } 3.000 \mathrm{~mL} \\
\text { ACN }\end{array}$ & 3.1 \\
\hline $25 x-3$ & $\begin{array}{l}\text { Combine } 1.000 \mathrm{~mL} 25 x-4 \text { Stock with } 3.000 \mathrm{~mL} \\
\text { ACN }\end{array}$ & 0.78 \\
\hline $25 x-2$ & $\begin{array}{l}\text { Combine } 1.000 \mathrm{~mL} 25 x-3 \text { Stock with } 3.000 \mathrm{~mL} \\
\text { ACN }\end{array}$ & 0.2 \\
\hline $25 x-1$ & $\begin{array}{l}\text { Combine } 1.000 \mathrm{~mL} 25 x-2 \text { Stock with } 3.000 \mathrm{~mL} \\
\text { ACN }\end{array}$ & 0.049 \\
\hline
\end{tabular}

Table 1: Preparation of 25x me-IPA stocks in ACN (in 8-mL amber glass vials). 


\begin{tabular}{|c|c|c|c|}
\hline \multirow[b]{2}{*}{ ID } & & \multicolumn{2}{|c|}{ Concentration $(\mu \mathrm{g} / \mathrm{mL})$} \\
\hline & & me-IPA & et-IPA \\
\hline $4 x-7$ & $\begin{array}{l}0.200 \mathrm{~mL} 25 x-7+0.200 \mathrm{~mL} 25 x \\
\text { Surrogate }+0.850 \mathrm{~mL} A C N\end{array}$ & 32 & 1.6 \\
\hline $4 x-6$ & $\begin{array}{l}0.200 \mathrm{~mL} 25 x-6+0.200 \mathrm{~mL} 25 x \\
\text { Surrogate }+0.850 \mathrm{~mL} A C N\end{array}$ & 8 & 1.6 \\
\hline $4 x-5$ & $\begin{array}{l}0.200 \mathrm{~mL} 25 x-5+0.200 \mathrm{~mL} 25 \mathrm{x} \\
\text { Surrogate }+0.850 \mathrm{~mL} \mathrm{ACN}\end{array}$ & 2 & 1.6 \\
\hline $4 x-4$ & $\begin{array}{l}0.200 \mathrm{~mL} 25 \mathrm{x}-4+0.200 \mathrm{~mL} 25 \mathrm{x} \\
\text { Surrogate }+0.850 \mathrm{~mL} \mathrm{ACN}\end{array}$ & 0.5 & 1.6 \\
\hline $4 x-3$ & $\begin{array}{l}0.200 \mathrm{~mL} 25 x-3+0.200 \mathrm{~mL} 25 x \\
\text { Surrogate }+0.850 \mathrm{~mL} \mathrm{ACN}\end{array}$ & 0.12 & 1.6 \\
\hline $4 x-2$ & $\begin{array}{l}0.200 \mathrm{~mL} 25 x-2+0.200 \mathrm{~mL} 25 x \\
\text { Surrogate }+0.850 \mathrm{~mL} A C N\end{array}$ & 0.031 & 1.6 \\
\hline $4 x-1$ & $\begin{array}{l}0.200 \mathrm{~mL} 25 \mathrm{x}-1+0.200 \mathrm{~mL} 25 \mathrm{x} \\
\text { Surrogate }+0.850 \mathrm{~mL} \mathrm{ACN}\end{array}$ & 0.008 & 1.6 \\
\hline $4 x-0$ & $\begin{array}{l}0.200 \mathrm{~mL} 25 x \text { Surrogate }+1.050 \\
\mathrm{~mL} \mathrm{ACN}\end{array}$ & 0 & 1.6 \\
\hline
\end{tabular}

Table 2: Preparation of 4x IPA stocks in ACN (in 2-mL autosampler vials).

\begin{tabular}{|c|c|c|c|}
\hline \multirow[b]{2}{*}{ ID } & & \multicolumn{2}{|c|}{ Concentration $(\mu \mathrm{g} / \mathrm{mL})$} \\
\hline & & me-IPA & et-IPA \\
\hline Std 7 & $0.200 \mathrm{~mL} 4 \mathrm{x}-7+0.600 \mathrm{~mL}$ DI water & 8 & 0.4 \\
\hline Std 6 & $0.200 \mathrm{~mL} 4 \mathrm{x}-6+0.600 \mathrm{~mL}$ DI water & 2 & 0.4 \\
\hline Std 5 & $0.200 \mathrm{~mL} 4 \mathrm{x}-5+0.600 \mathrm{~mL}$ DI water & 0.5 & 0.4 \\
\hline Std 4 & $0.200 \mathrm{~mL} 4 \mathrm{x}-4+0.600 \mathrm{~mL}$ DI water & 0.13 & 0.4 \\
\hline Std 3 & $0.200 \mathrm{~mL} 4 \mathrm{x}-3+0.600 \mathrm{~mL}$ DI water & 0.03 & 0.4 \\
\hline Std 2 & $0.200 \mathrm{~mL} 4 \mathrm{x}-2+0.600 \mathrm{~mL}$ DI water & 0.0078 & 0.4 \\
\hline Std 1 & $0.200 \mathrm{~mL} 4 \mathrm{x}-1+0.600 \mathrm{~mL}$ DI water & 0.002 & 0.4 \\
\hline Std 0 & $0.200 \mathrm{~mL} 4 \mathrm{x}-0+0.600 \mathrm{~mL}$ DI water & 0 & 0.4 \\
\hline Blank & $\begin{array}{l}0.200 \mathrm{~mL} \mathrm{ACN}+0.600 \mathrm{~mL} \mathrm{DI} \\
\text { water }\end{array}$ & 0 & 0 \\
\hline
\end{tabular}

Table 3: Preparation of me-IPA standards in 75/25 water/ACN (in 2-mL autosampler vials).

\begin{tabular}{|c|c|c|c|}
\hline & & \multicolumn{2}{|c|}{ Concentration $(\mu \mathrm{g} / \mathrm{mL})$ in serum } \\
\hline ID & & me-IPA & et-IPA \\
\hline Negative Control & $\begin{array}{l}0.050 \mathrm{~mL} 25 x \text { Surrogate }+0.950 \\
\mathrm{~mL} \text { Diluent }\end{array}$ & 0 & 10 \\
\hline Low Fortification & $\begin{array}{l}0.050 \mathrm{~mL} 25 x \text { Surrogate }+0.020 \\
\mathrm{~mL} 25 \mathrm{x}-4+0.930 \mathrm{~mL} \text { Diluent }\end{array}$ & 1.2 & 10 \\
\hline Mid Fortification & $\begin{array}{l}0.050 \mathrm{~mL} 25 x \text { Surrogate }+0.030 \\
\mathrm{~mL} 25 \mathrm{x}-6+0.920 \mathrm{~mL} \text { Diluent }\end{array}$ & 30 & 10 \\
\hline High Fortification & $\begin{array}{l}0.050 \mathrm{~mL} 25 x \text { Surrogate }+0.020 \\
\mathrm{~mL} 25 \mathrm{x}-7+0.930 \mathrm{~mL} \text { Diluent }\end{array}$ & 80 & 10 \\
\hline
\end{tabular}

Table 4: Quality control sample fortification (prepare in 1.5-mL microcentrifuge tubes). 


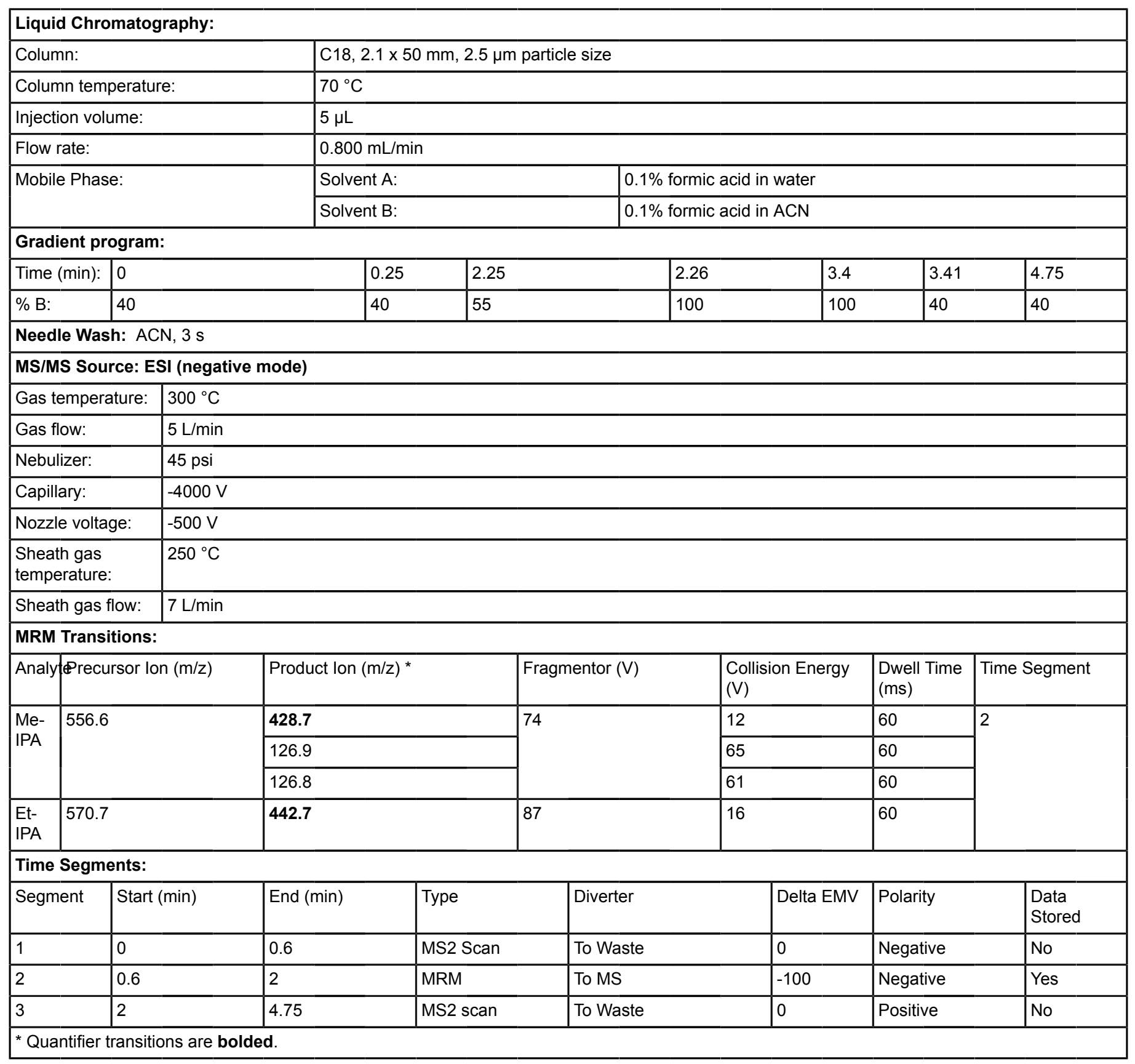

Table 5: LC-MS/MS parameters. Quantifier product ions are bolded. 


\begin{tabular}{|c|c|c|c|c|c|c|}
\hline & & Target & Observed & Percent & & \\
\hline ID & Day & me-IPA & me-IPA & Recovery & & \\
\hline QC-1 & 1 & 0 & ND & N/A & & \\
\hline QC-2 & 1 & 0 & ND & N/A & & \\
\hline QC-11 & 2 & 0 & ND & N/A & & \\
\hline QC-12 & 2 & 0 & ND & N/A & & \\
\hline QC-21 & 3 & 0 & ND & N/A & & \\
\hline QC-22 & 3 & 0 & ND & N/A & & \\
\hline QC-31 & 4 & 0 & ND & N/A & & \\
\hline QC-32 & 4 & 0 & ND & N/A & & \\
\hline QC-3 & 5 & 0 & ND & N/A & & \\
\hline QC-4 & 5 & 0 & ND & N/A & & \\
\hline QC-13 & 1 & 1.25 & 1.26 & $101 \%$ & $\operatorname{Ave}_{(10)}=$ & $102 \%$ \\
\hline QC-14 & 1 & 1.25 & 1.23 & $98.40 \%$ & $S D=$ & $3.50 \%$ \\
\hline QC-23 & 2 & 1.25 & 1.26 & $101 \%$ & $\%$ RSD $=$ & $3.40 \%$ \\
\hline QC-24 & 2 & 1.25 & 1.28 & $102 \%$ & & \\
\hline QC-33 & 3 & 1.29 & 1.3 & $101 \%$ & & \\
\hline QC-34 & 3 & 1.29 & 1.25 & $96.90 \%$ & & \\
\hline QC-5 & 4 & 1.29 & 1.37 & $106 \%$ & & \\
\hline QC-6 & 4 & 1.29 & 1.41 & $109 \%$ & & \\
\hline QC-15 & 5 & 1.29 & 1.3 & $101 \%$ & & \\
\hline QC-16 & 5 & 1.29 & 1.34 & $104 \%$ & & \\
\hline QC-25 & 1 & 30.1 & 30.2 & $100 \%$ & Ave $_{(10)}=$ & $103 \%$ \\
\hline QC-26 & 1 & 30.1 & 31.2 & $104 \%$ & $\mathrm{SD}=$ & $1.80 \%$ \\
\hline QC-35 & 2 & 30.1 & 31.1 & $103 \%$ & $\%$ RSD = & $1.70 \%$ \\
\hline QC-36 & 2 & 30.1 & 31.1 & $103 \%$ & & \\
\hline QC-7 & 3 & 31 & 31.6 & $102 \%$ & & \\
\hline QC-8 & 3 & 31 & 31.4 & $101 \%$ & & \\
\hline QC-17 & 4 & 31 & 32.5 & $105 \%$ & & \\
\hline QC-18 & 4 & 31 & 32.8 & $106 \%$ & & \\
\hline QC-27 & 5 & 31 & 31.7 & $102 \%$ & & \\
\hline QC-28 & 5 & 31 & 32.1 & $104 \%$ & & \\
\hline QC-37 & 1 & 80.2 & 77.8 & $97.00 \%$ & $\operatorname{Ave}_{(10)}=$ & $101 \%$ \\
\hline QC-38 & 1 & 80.2 & 78.9 & $98.40 \%$ & $\mathrm{SD}=$ & $2.30 \%$ \\
\hline QC-9 & 2 & 80.2 & 81.8 & $102 \%$ & $\%$ RSD = & $2.30 \%$ \\
\hline QC-10 & 2 & 80.2 & 79.8 & $99.50 \%$ & & \\
\hline QC-19 & 3 & 82.7 & 83.5 & $101 \%$ & & \\
\hline QC-20 & 3 & 82.7 & 84 & $102 \%$ & & \\
\hline QC-29 & 4 & 82.7 & 84.7 & $102 \%$ & & \\
\hline QC-30 & 4 & 82.7 & 87.2 & $105 \%$ & & \\
\hline QC-39 & 5 & 82.7 & 83 & $100 \%$ & & \\
\hline QC-40 & 5 & 82.7 & 84.1 & $102 \%$ & & \\
\hline
\end{tabular}

Table 6: QC results for me-IPA in mongoose serum $(\mu \mathrm{g} / \mathrm{mL})$. 


\begin{tabular}{|l|l|l|l|l|}
\hline Target et-IPA $(\mu \mathrm{g} / \mathrm{mL})$ & $\mathrm{N}$ & Mean $(\%)$ & SD $(\%)$ & $\%$ RSD \\
\hline 0 & 21 & & & \\
\hline 1.3 & 12 & 103 & 4.5 & 4.3 \\
\hline 13 & 9 & 91.7 & 1.4 & 1.5 \\
\hline 32 & 12 & 106 & 2.4 & 2.3 \\
\hline 85 & 12 & 105 & 5.8 & 5.6 \\
\hline 170 & 9 & 106 & 1.1 & 1.1 \\
\hline
\end{tabular}

Table 7: QC results for et-IPA in mongoose serum $(\mu \mathrm{g} / \mathrm{mL})$.

\begin{tabular}{|c|c|c|c|c|c|c|c|c|}
\hline \multicolumn{9}{|c|}{ Bait type and ethyl IPA bait concentration $(\mu \mathrm{g} / \mathrm{mL})$} \\
\hline \multirow[t]{2}{*}{ Time Period } & \multicolumn{2}{|c|}{$0.4 \%$ - Blister } & \multicolumn{2}{|c|}{$1.0 \%$ - Blister } & \multicolumn{2}{|c|}{$0.14 \%$ - Matrix } & \multicolumn{2}{|l|}{ Control } \\
\hline & Mean (SD) & $N$ & Mean (SD) & $\mathrm{N}$ & Mean (SD) & $N$ & Mean (SD) & $\mathrm{N}$ \\
\hline Day 0 & ND & 5 & ND & 4 & ND & 6 & ND & 3 \\
\hline Day 1 & $13.7(10.9)$ & 2 & $11.2(10.4)$ & 4 & $20.6(17.3)$ & 2 & NA & NA \\
\hline Day 7 & $11.5(6.3)$ & 6 & $9.9(9.6)$ & 4 & $21.4(10.9)$ & 6 & ND & 3 \\
\hline Day 14 & $10.2(5.2)$ & 6 & $5.7(2.5)$ & 3 & $17.8(10.2)$ & 6 & ND & 3 \\
\hline Day 21 & $8.9(4.1)$ & 4 & $10.0(9.5)$ & 4 & $23.8(5.3)$ & 3 & ND & 2 \\
\hline Day 28 & $8.5(3.9)$ & 5 & 11.1 (10.6) & 3 & $17.7(9.3)$ & 4 & ND & 3 \\
\hline Day 35 & 17.0 (NA) & 1 & $9.1(9.0)$ & 4 & $21.7(9.3)$ & 2 & ND & 1 \\
\hline Day 42 & NA & 0 & $8.4(8.5)$ & 4 & 16.5 (NA) & 1 & ND & 2 \\
\hline Day 49 & $10.2(5.8)$ & 2 & $8.1(8.4)$ & 4 & $17.5(4.7)$ & 2 & ND & 2 \\
\hline Day 56 & $10.9(5.4)$ & 2 & $3.8(1.1)$ & 3 & $17.6(6.1)$ & 2 & ND & 2 \\
\hline
\end{tabular}

Table 8: Mean (stand deviation [SD]) ethyl-IPA serum concentration by bait type. ND = not detected, NA = Not applicable.

\begin{tabular}{|c|c|c|c|c|c|c|c|c|}
\hline \multicolumn{9}{|c|}{ Dose and methyl IPA concentration $(\mu \mathrm{g} / \mathrm{mL})$} \\
\hline \multirow[t]{2}{*}{ Time Period } & \multicolumn{2}{|l|}{$0.04 \%$} & \multicolumn{2}{|l|}{$0.07 \%$} & \multicolumn{2}{|l|}{$0.14 \%$} & \multicolumn{2}{|l|}{ Control } \\
\hline & Mean (SD) & $N$ & Mean (SD) & $\mathrm{N}$ & Mean (SD) & $\mathrm{N}$ & Mean (SD) & $\mathrm{N}$ \\
\hline Day 0 & ND (NA) & 4 & ND (NA) & 4 & ND (NA) & 4 & ND (NA) & 4 \\
\hline Day 1 & $7.8(7.1)$ & 4 & $22.2(9.2)$ & 4 & $29.1(16.0)$ & 4 & ND (NA) & 4 \\
\hline Day 7 & $4.4(4.8)$ & 4 & $14.4(4.6)$ & 4 & $21.3(12.0)$ & 4 & ND (NA) & 4 \\
\hline Day 14 & $5.7(5.9)$ & 4 & $12.0(3.5)$ & 4 & $19.6(10.6)$ & 4 & ND (NA) & 4 \\
\hline Day 21 & $4.9(4.5)$ & 4 & $12.0(0.8)$ & 3 & $18.3(9.9)$ & 4 & ND (NA) & 4 \\
\hline Day 28 & $5.4(5.0)$ & 4 & $9.8(2.4)$ & 4 & $16.4(8.1)$ & 4 & ND (NA) & 4 \\
\hline
\end{tabular}

Table 9: Mean (SD) methyl-IPA serum concentration by dose. ND = Not detected, NA = Not applicable. All methyl IPA concentrations were incorporated into the external bait matrix.

\section{Discussion}

The LC-MS/MS method developed for the studies utilized the selectivity of multiple reaction monitoring to accurately quantify me-IPA and et-IPA in mongoose serum. The selectivity of MS/MS detection also allowed for a simple clean-up protocol relying solely on acetonitrile to precipitate proteins from serum prior to analysis.

lophenoxic acids are soluble in ACN but are practically insoluble in water. To exclude water from the ACN extraction, sodium chloride was added to force a clear water:ACN phase separation by increasing the ionic strength of the aqueous (serum) phase. The volatile acid trifluoracetic acid (TFA) was also added to ensure that iophenoxic acids were protonated during the extraction and would be more readily solubilized in the ACN phase. TFA is removed during the dry-down step prior to LC-MS/MS analysis.

Blood draws from mongoose were approximately $1 \mathrm{~mL}$, yielding $0.5 \mathrm{~mL}$ or less of sera. To perform replicate analyses of each sample, a microscale sample preparation procedure was required that used microcentrifuge tubes rather than typical analytical laboratory glassware such as Class A volumetric pipettes and flasks. To achieve accurate and precise results it is necessary that analysts be proficient in the use of glass microliter syringes and positive-displacement repeat pipettors with microliter-size tips. 
A limitation of this method is that it requires costly LC-MS/MS instrumentation and analysts trained in its use and maintenance. However, because me-IPA and et-IPA are baseline resolved using the HPLC conditions described, the method could potentially be adapted to a singlequadrupole LCMS or HPLC with UV detector provided no interferences were observed.

The difference in mean serum concentrations between mongooses that consumed baits with et-IPA in the blister pack and bait matrix at the $2.8 \mathrm{mg}$ dose suggests spillage when the marker is contained in the blister pack, rather than incorporated into the bait matrix. This may have implications for the purpose of estimating vaccine as opposed to bait uptake. For example, incorporating the marker into the external bait matrix may inflate the estimation of vaccine coverage if the animal eats the matrix but vaccine spills out. However, regulatory restrictions may preclude the ability of mixing a biological marker directly with a vaccine within the blister pack. In the cases in which $<100 \%$ consumption was recorded, three cases were with baits containing et-IPA in the blister pack, two of which were the higher $1 \%$ concentration. This suggests potential taste aversion when et-IPA is at higher concentrations. When baits containing $1 \%(20.0 \mathrm{mg})$ et-IPA incorporated into the bait matrix were offered to mongooses, all animals rejected the bait.

Mean IPA concentrations for et- and me-IPA at day 14 were approximately 17 and $19 \mu \mathrm{g} / \mathrm{mL}$, respectively. Similar research performed at Instituto de Investigación en Recursos Cinegéticos, Ciudad Real, Spain, using butyl and pentyl-IPA found day 14 concentrations of approximately 45 and $10 \mu \mathrm{g} / \mathrm{mL}$ in mongoose sera when delivered at the same concentration and bait formulation as in our study. These differences suggest that different derivatives of IPA may metabolize at different rates in mongooses, which can be useful when marker retention (either short or long-term retention) is a concern.

Differences in the physiology of the gastrointestinal system may affect absorption and excretion of IPA in different species. The plasma elimination half-life of IPA in domestic cats (Felis catus) when delivered at $1.5 \mathrm{mg} / \mathrm{kg}$ was 107 days whereas the rate in brushtail possums at the same dose rate was approximately one day ${ }^{28}$. When IPA was given to domestic goats (Capra aegagrus hircus) at a dose rate of $1.5 \mathrm{mg} / \mathrm{kg}$ the terminal elimination half-life of IPA was 81 days, although investigators continued to find elevated iodine concentrations up to 160 days following administration ${ }^{39}$. The gastrointestinal system of members of Vivveridae (the family to which mongooses had previously been assigned ${ }^{40}$ ) is described as similar to that of the domestic cat ${ }^{41}$, which may explain the retention time of IPA in mongooses. Research also suggests IPA may be metabolized differently in marsupials, allowing for more rapid excretion than in eutherian species ${ }^{29}$.

Both derivatives of IPA evaluated in this study provided long-term (4-8 weeks) marking ability in mongooses. The use of IPA as a biological marker in mongooses should take into consideration the study objectives and the desired duration of marking. In cases where animals are to be marked from the same study sites during consecutive time periods, different derivatives of IPA could be used to ensure results from one marking event are not confounded by marking during previous events. As part of operational ORV for wildlife in the US, sampling the target species and testing for the presence of RVNA and biomarker is typically conducted 4-6 weeks following ORV distribution ${ }^{42}$. From a practical standpoint, it appears either et- or me-IPA can be readily detected during this time period. Future research to evaluate the residue decay function in mongooses offered various concentrations of both congeners of IPA evaluated in this study would be useful.

\section{Disclosures}

Authors $\mathrm{AV}$ and $\mathrm{SO}$ are fulltime employees of an oral rabies vaccine bait manufacturer.

\section{Acknowledgments}

This research was supported in part by the intramural research program of the US Department of Agriculture, Animal and Plant Health Inspection Service, Wildlife Services, National Rabies Management Program and IDT Biologika (Dessau-Rosslau, Germany).

\section{References}

1. Nel, L.H. et al. Mongoose rabies in southern Africa: a re-evaluation based on molecular epidemiology. Virus Research. 109 (2), 165-173 (2005).

2. Zieger, Z. et al. The phylogeography of rabies in Grenada, West Indies, and implications for control. PLOS Neglected Tropical Diseases. 8 (10), e3251 (2004).

3. Monroe, B.P. et al. Rabies surveillance in the United States during 2014. Journal of the American Veterinary Medical Association. 248 (7), 777-788 (2015).

4. Slate, D. et al. Status of oral rabies vaccination in wild carnivores in the United States. Virus Research. 111, 68-76 (2005).

5. Blanton, J.D. et al. Vaccination of small Asian mongoose (Herpestes javanicus) against rabies. Journal of Wildlife Diseases. 42 (3), $663-666$ (2006).

6. Vos, A. et al. Oral vaccination of captive small Indian mongoose (Herpestes auropunctatus) against rabies. Journal of Wildlife Diseases. 49 (4), 1033-1036 (2013).

7. Berentsen, A.R., Johnson, S.R., VerCauteren, K.C. Evaluation of ONRAB ${ }^{\circledR}$ bait matrix flavor preference by mongoose (Herpestes auropunctatus) in Puerto Rico: Implications for Oral Rabies Vaccination. Caribbean Journal of Science. 48 (1), 52-58 (2014).

8. Ortmann, S. et al. Safety studies with the oral rabies virus vaccine strain SPBN GASGAS in the small Indian mongoose (Herpestes auropunctatus). BMC Veterinary Research. 14 (1), 90 (2018).

9. Linhart, S.B. et al. A field evaluation of baits for delivering oral rabies vaccines to raccoons (Procyon lotor). Journal of Wildlife Diseases. $\mathbf{3 0}$ (2), 185-194 (1994).

10. Fry, T.L., Atwood, T., Dunbar, M.R. Evaluation of rhodamine B as a biomarker for raccoons. Human Wildlife Interactions. 4 (2), 275-282 (2010).

11. Jones, C., Moller, H., Hamilton, W. A review of potential techniques for identifying individual stoats (Mustela erminea) visiting control or monitoring stations. New Zealand Journal of Zoology. 31 (3), 193-203 (2004). 
12. de Leeuw, A. N.S., Smith, G.C., Woods, J.A. Use of iophenoxic acid to assess bait uptake by European badgers. Advances in Vertebrate Pest Management. 4, 243-254 (2006).

13. Southey, A.K., Sleeman, D.P., Gormley, E. Sulfadimethoxine and rhodamine B as oral biomarkers for European badgers (Meles meles). Journal of Wildlife Diseases. 38 (2), 378-384 (2002).

14. Massei, G., Jones, A., Platt, T., Cowan, D.P. Iophenoxic Acid as a Long-Term Marker for Wild Boar. Journal of Wildlife Management. 73 (3), 458-461 (2009).

15. Creekmore, T.E. et al. Field evaluation of baits and baiting strategies for delivering oral vaccine to mongooses in Antigua, West Indies. Journal of Wildlife Diseases. 30 (4), 497-505 (1994).

16. Creekmore, T.E., Rock, R.E., Hurley, J. A baiting system for delivery of an oral plague vaccine to black-tailed prairie dogs. Journal of Wildlife Diseases. 38 (1), 32-39 (2002).

17. Fernandez, J.R-R., Rocke, R.E. Use of Rhodamine B as a biomarker for oral plague vaccination of prairie dogs. Journal of Wildlife Diseases. 47 (3), 765-768 (2011).

18. Johnston, J.J. et al. Evaluation and significance of tetracycline stability in rabies vaccine baits. Journal of Wildlife Diseases. 41 (3), $549-558$ (2005).

19. Algeo, T.P. et al. Oral rabies vaccination variation in tetracycline biomarking among Ohio Raccoons. Journal of Wildlife Diseases. 49 (2), 332-337 (2013).

20. Crier, J.K. Tetracyclines as a fluorescent marker in bones and teeth of rodents. Journal of Wildife Management. 34 (4), $829-834$ (1970).

21. Fisher, P. Review of using Rhodamine B as a marker for wildlife studies. Wildlife Society Bulletin. 27 (2), 318-329 (1999).

22. Knowlton F.K., Savarie, P.J, Wahlgren, C.E., Hayes, D.J. Physiological marks by coyotes ingesting baits containing iophenoxic acid, Mirex and Rhodamine B. Vertebrate Pest Control and Management Materials: $5^{\text {th }}$ Volume. ASTM STP 974, S. A. Shumake and R. W. Bullard, Eds. American Society for Testing and Materials, Philadelphia, 141-147 (1987).

23. Follmann, E.H., Savarie, P.J., Ritter, D.G., Baer, G.M. Plasma marking of arctic foxes with iophenoxic acid. Journal of Wildlife Diseases. 23 (4), 709-712 (1987)

24. Saunders, G., Harris, S., Eason, C. T. lophenoxic acid as a quantitative bait marker for foxes. Wildlife Research. 20, 297-302 (1993).

25. Hadidian, J. et al. Acceptance of simulated oral rabies vaccine baits by urban raccoons. Journal of Wildlife Diseases. 25 (1), 1-9 (1989).

26. Sweetapple, P.J., Nugent, G. Iophenoxic acid as a serum marker for red deer (Cervus elaphus scoticus). Wildlife Research. 25, 649-654 (1998).

27. Ogilvie, S.C., Eason, C.T. Evaluation of iophenoxic acid and rhodamine B for marking feral ferrets (Mustela furo). New Zealand Journal of Zoology. 25 (2), 105-108 (1998).

28. Eason, C. T., Batcheler, D., Frampton, C. M. Comparative pharmacokinetics of iophenoxic acid in cats and brushtail possums. Wildlife Research. 21, 377-380 (1994).

29. Fisher, P.M., Marks, C.A. Evaluation of iophenoxic acid as a biomarker for swamp wallabies (Wallabia bicolor). Wildlife Research. 24, 97-103 (1997).

30. Baer, G.M., Shaddock, J.H., Hayes, D.J., Savarie, P. Iophenoxic acid as a serum marker in carnivores. Journal of Wildlife Management. 49 (1), 49-51 (1985).

31. Spurr, E. B. lophenoxic acid as a systemic blood marker for assessment of bait acceptance by stoats (Mustela ermine) and weasels (Mustela nivalis). New Zealand Journal of Zoology. 29 (2), 135-142 (2002).

32. Mudge, G.H., Strewler, G.J., Desbiens, N., Berndt, W.O., Wade, D.N. Excretion and distribution of iophenoxic acid. Journal of Pharmacology and Experimental Therapeutics. 178 (1), 159-172 (1971).

33. Jones, A. High-performance liquid chromatographic determination of iophenoxic acid in serum. Journal of Chromatography B: Biomedical Sciences and Applications. 654 (2), 293-296 (1994).

34. Wiles, M.C., Campbell, T.A. Liquid chromatography-electrospray ionization mass spectrometry for direct identification and quantification of iophenoxic acid in serum. Journal of Chromatography B. 832 (1), 144-157 (2006).

35. Ballesteros, C. et al. Analysis by LC/ESI-MS of iophenoxic acid derivatives and evaluation as markers of oral baits to deliver pharmaceuticals to wildlife. Journal of Chromatography B. 878 (22), 1997-2002 (2010).

36. Purdey, D.C., Petcu, M., King, C.M. A simplified protocol for detecting two systemic bait markers (Rhodamine B and iophenoxic acid) in small mammals. New Zealand Journal of Zoology. 30 (3), 175-184 (2003).

37. Tobin, M.E., Koehler, A.E., Sugihara, R. Tetracyclines as a fluorescent marker in bones and teeth of rodents. Journal of Wildlife Management. 60 (1), 202-207 (1996).

38. Briscoe, J.A., Syring, R. Techniques for emergency airway and vascular access in special species. Seminars in Avian and Exotic Pet Medicine. 13 (3), 118-131 (2004).

39. Eason, C.T., Frampton, C.M. The plasma pharmacokinetics of iophenoxic and iopanoic acids in goat. Xenobiotica. 2 (2), 185-189 (1992).

40. Hilton, H.E., Dunn, A.M.S. Mongooses: their natural history and behavior. Oliver and Boyd, Edinburgh and London (1967).

41. Stevens, C. E., Hume, I. D. Comparative physiology of the vertebrate digestive system. Second edition. Cambridge University Press, Cambridge (1995).

42. National Rabies Management Program (NRMP). Oral rabies vaccination draft operations manual. USDA APHIS Wildlife Services, (2009). 